\title{
CLOTHES MAKE THE (WO)MAN
}

\begin{abstract}
In the Pauline letters a new rhetorical aspect of body is presented with the imagery of

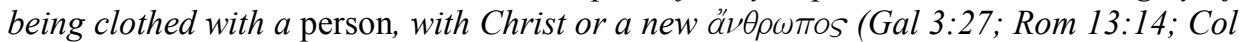
3:10; Eph 4:24). While body and clothing imagery was well-known in the ancient Mediterranean world, the picture of putting on a person is new with these passages. Clothing has implications for movement and identification, but there is also interweaving between body, mind and clothing related to how humans present themselves, how they interact socially, how they are empowered morally and politically, and how they produce rhetorical and political discourse. This essay offers a socio-rhetorical interpretation of the texts that speak of being clothed with a person, considering the implications for those who become so clothed. This clothing refashions bodies with new religious, social and political roles. Refashioned bodies become agents of social change. The new clothing makes new persons and a new social reality.
\end{abstract}

Keywords: Clothing, Ideology, Identity, Behaviour, Transformation, Socio-rhetorical Interpretation

Costly thy habit as thy purse can buy,

But not express'd in fancy; rich, not gaudy;

For the apparel oft proclaims the man,

And they in France of the best rank and station

Are of a most select and generous clef in that.

(Polonius, Hamlet Act 1 Scene 3)

Thinking about perceptions of body as they are used in the Bible leads, inevitably, to reflecting on clothing and the idea of clothing. Clothing is a powerful image throughout biblical literature and in human society generally. ${ }^{1}$ At the most obvious level, clothing covers and conceals the body, protecting it from exposure to the elements and the view of other persons. But the significance of clothing extends much further since garments not only cover and conceal, but also function to display the body in particular ways and with many meanings. The ways in which bodies are clothed have far-reaching and sometimes dramatic implications for identity, for movement, for relationships with others, for behaviour, for economic, social and spiritual status, for sexual roles, and for religious, ideological and political discourse. Clothing is part of how people are presented to the world, of how they relate socially, and of how they are empowered morally and politically. Clothing is a feature of the body shapes and actions that are offered for view and that differentiate people from one another. Clothing is thus tied to recognition. Humans are

For general information about clothing and the imagery of clothing in the Bible see Edwards, DR 1992. Dress and Ornamentation. Pages 232-238 in vol. 2 of Anchor Bible Dictionary. Edited by DN Freedman. 6 vols. New York: Doubleday; and 1998. Garments. Pages 317-320 in Dictionary of Biblical Imagery. Edited by L Ryken, JC Wilhoit and T Longman III. Downers Grove: InterVarsity Press. 
frequently recognized and defined by the clothes that they wear. Dressing, undressing and redressing have literal, symbolic and rhetorical connotations that define people and social realities. $^{2}$

The description and imagery of clothing occurs throughout the Bible. There are many notable examples. Adam and Eve fashioned leaves together to cover their nakedness (Gen 3:7) and were subsequently clothed with skins by God (Gen 3:21). The image of clothing is prominent in the Joseph cycle of stories (Gen 37-45) where Joseph receives a special robe from his father, Jacob, with the favouritism indicated thereby arousing hatred toward Joseph among his brothers (Gen 37:3-4). The robe is removed from Joseph, indicating his enforced fall from favour, and then is used to deceive Jacob into thinking that Joseph was dead, at which point Jacob tears his own garments in a show of grief (Gen 37:23-35). In Egypt, Joseph's clothing plays a role in his avoidance of the sexual advances of Potiphar's wife and in the false accusation made against him (Gen 39:12-18). Later, when Joseph is restored to dignity, he is given fine garments by the Pharaoh (Gen 41:41-42) and, when Joseph and his brothers are reconciled, he provides garments for all of them (Gen 45:22). Embedded within the Joseph story is the incident involving Judah and Tamar, where Tamar indicates her availability to Judah as a prostitute by the way she clothes herself (Gen 38:1415). The priests of ancient Israel wore special clothing or vestments in which they performed their sacerdotal duties (Exod 28:1-43). These vestments were consecrated and to be passed on through generations (Exod 29:1-29). Hannah's annual provision of a robe for Samuel demonstrates her dedication to the son who was given to her (1 Sam 2:19). In the Hebrew Bible the image of being clothed not with a garment but with a particular attribute occurs in some passages (e.g., 2 Chr 6:41; Job 8:22; Ps 35:26; 132: 9, 16, 18). Even God is "clothed with honour and majesty, wrapped in light as with a garment" (Ps 104:1-2). In the NT, the newborn Jesus is wrapped in bands of cloth which serve, in part, to identify him (Luke 2:7, 12). At the transfiguration, Jesus' clothing became "dazzling white" (Matt 17:2; Mark 9:3; Luke 9:29). A woman merely touches the edge of Jesus' garment and is healed (Luke 8:43-48). The very best robe symbolizes the acceptance and restoration of the prodigal son by his father (Luke 15:22). Paul addresses the veiling of women in 1 Cor 11:216. ${ }^{3}$ According to Rev 7:9-17, the members of an innumerable, multiethnic, multilingual, celebrating crowd are clothed in white robes that have been made white by having been washed in the blood of the lamb.

\section{A Rhetoric of Clothing}

There are many more portrayals of clothing in the Bible, but what emerges is that there is a rhetoric of clothing employed in many texts. This should not be surprising given the pervasive nature of the images of body and clothing in world cultures. Among all creatures, only humans intentionally use garments in nearly countless colours, styles and fashions and

2 Clothing functions to indicate personal identities, social and cultural positions and roles. For example, garments worn may indicate that one is male, female, young, old, wealthy, poor, monarch, peasant, priest, minister, civilian, soldier, athlete, prisoner, judge, academic or many other things. A redressed person may be a re-formed or re-presented person, one who has a changed identity and a changed social role. On this see Lurie, A 1981. The Language of Clothes. New York: Random House, 3-36.

3 On this see Martin, TW 2004. Paul's Argument from Nature for the Veil in 1 Corinthians 11:13-15: A Testicle Instead of a Head Covering. Journal of Biblical Literature 123(1):75-84; and Martin, TW Forthcoming. Veiled Exhortations Regarding the Veil: Ethos as the Controlling Factor in Moral Persuasion (1 Cor 11:2-16). In Rhetoric, Ethic and Moral Persuasion in Biblical Discourse: Essays from the 2002 Heidelberg Conference. Edited by TH Olbricht and A Eriksson. New York: T \& T Clark International. 
with as many implications. ${ }^{4}$ The purpose of such widespread fashion is to provide nonverbal communication, and it is clear that people do pay attention to what is communicated by clothing. ${ }^{5}$ This has recently been made evident in socio-historical studies of Chen, who has investigated the intentional use of clothing and body as a communicative device in Maoist China. ${ }^{6}$ Chen (2003a, 361) describes and analyzes the effect of Mao's concern that "what was needed for perfection of body and mind was physical transformation that could elicit reconstitution of the mind." Clothing was one of the things employed to bring about these changes resulting in "a discourse of proletarian dress and body" supportive of the aims and politics of the regime in China. The use of garments in this way is observable in photographs, drawings and literature from the period. The physical human body of some populations was symbolically reformed by changes in clothing from what was customarily worn in the pre-1949 period to what was worn subsequently. ${ }^{8}$ This physicality was deemed to be necessary for the transformation of people into good socialist members of the larger ideological community. A change of garments produced refashioned bodies that had new social roles and minds with a new social consciousness. The rhetoric of clothing that developed became interwoven ${ }^{9}$ with a variety of political projects initiated by the Maoist government. ${ }^{10} \mathrm{~A}$ rhetoric of clothing can bring about changes of appearance, identity, behaviour and social meaning that function to bring about intellectual and social change. Body and clothing together become a symbolic system by means of which life becomes reconfigured and culture becomes altered. ${ }^{11}$ The goal of this rhetoric is, interestingly, to bring about change that leads, eventually, to conformity to a particular ideology and way of life.

\section{Clothing the Body in the Pauline Letters}

In the Pauline letters the image of body is prominent in many places, particularly in the well-known "body of Christ" passages. In other texts the believer's body, while described as already a temple of God (1 Cor 3:16-17; 6:19), is in a state of transition or conformity to Christ's body and righteousness (e.g., Rom 6:5-6; 8:10-13; 12:1-2; 2 Cor 4:8-11; Phil 3:21), and awaits glory (e.g., Rom 8:18-23; 1 Cor 15:35-54; 2 Cor 4:16-5:10; Phil 3:21). ${ }^{12}$ The description of body and clothing is also very significant on its own (e.g., 1 Cor 12:22-24; 2

4 See Fowles, J 1974. Why We Wear Clothes. ETC: A Review of General Semantics 31(4):343-352.

5 Fowles (1974, 344, 350), and Lurie (1981, 3-36). Clothing can elicit delight, sexual arousal, mourning, fear, disgust, peacefulness, awe, strength, joy, and many other things. Actually, humans and their bodies lose identity without clothing. Apart from the obvious, one cannot distinguish a king from a servant or an archbishop from a prostitute when they stand together naked.

6 Chen, TM 2003a. Proletarian White and Working Bodies in Mao's China. Positions 11(2):361-393; see also Chen, TM 2003b. Female Icons, Feminist Iconography? Socialist Rhetoric and Women's Agency in 1950's China. Gender and History 15(2):268-295.

7 Chen (2003a, 362).

8 See Chen (2003a, 364-368).

9 In socio-rhetorical terms, there are many interweavings or "textures" to be considered. See Robbins, VK 1996a. Exploring the Texture of Texts: A Guide to Socio-Rhetorical Interpretation. Valley Forge: Trinity Press International.

10 Chen (2003a, 388).

11 Chen (2003a, 363). Other examples might include the distinctive garments worn by members of some Mennonite and other Anabaptist communities.

12 See Sandnes, KO 2002. Belly and Body in the Pauline Epistles. Society for New Testament Studies Monograph Series 120. Cambridge: Cambridge University Press, 15-21; Dunn, JDG 1998. The Theology of Paul the Apostle. Grand Rapids: Eerdmans, 489-490. 
Cor 5:1-10; Eph 6:13-17). Some passages do, however, go on to employ the garment and

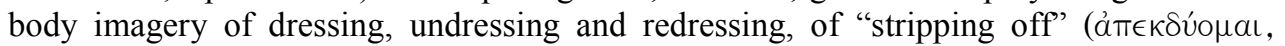

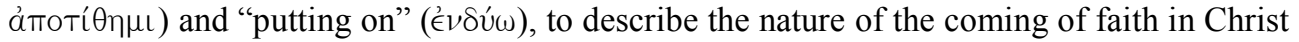
(Gal 3:27) and to encourage moral and behavioral change and an altered focus of living (Rom 13:14; Col 3:8-10; Eph 4:22-24). This rhetorical topos of stripping off and putting on clothing was well known and fairly widely employed in the ancient Mediterranean world as a means of encouraging people to adopt appropriate qualities and behaviours. ${ }^{13}$ What is new to the topos in these Pauline passages is the rhetoric of being clothed with a person. ${ }^{14}$ To this image there appears to be no clear parallel in ancient literature. ${ }^{15}$ The concern of this essay is to examine what the rhetoric of putting on a person does to and for its audiences. What follows will offer a socio-rhetorical interpretation of this rhetorical image in NT discourse and its implications for behaviour and a political discourse of body. Putting on the new person suggests the production of a refashioned body that has new religious, social and political roles in the world. Refashioned bodies become agents of social change. ${ }^{16}$ The body displayed by a garment that is a person can bring about new social realities. ${ }^{17}$ The interest here, then, is not to provide a source critical study of the origin and provenance of the language of putting on a new person, but to see how it is (re)configured to make a socio-rhetorical point in the early Christian situation. ${ }^{18}$

\section{A Socio-Rhetorical Approach}

As it has been developing, ${ }^{19}$ Socio-Rhetorical Interpretation has aimed to produce a multidimensional interpretive analytic that takes into account many methods and insights of various kinds, and is constantly "drawing and redrawing boundaries of analysis and interpretation" as it goes along. ${ }^{20}$ It brings together study of the literary, socio-cultural,

13 Some examples include Philo, Conf. 31; Ep. Arist. 122; 1QS 4:2-5:10. On this see the commentaries and, especially, Van der Horst, PW 1972-1973. Observations on a Pauline Expression. New Testament Studies 19:181-187.

14 O'Brien, PT 1999. The Letter to the Ephesians. Grand Rapids: William B Eerdmans Publishing Company, 327. Cf. Thompson, MB 1991. Clothed With Christ: The Example and Teaching of Jesus in Romans 12.115.23. Journal for the Study of the New Testament: Supplement Series 59. Sheffield: Sheffield Academic Press, 150.

15 Dunn, JDG 1988. Romans 9-16. Word Biblical Commentary 38A. Dallas: Word, 790, cites Dionysius of

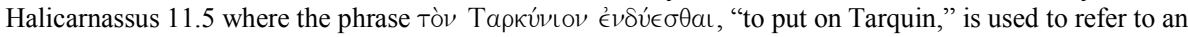

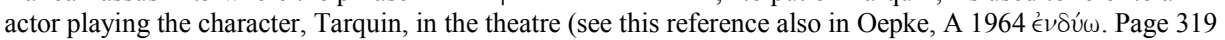
in vol. II of Theological Dictionary of the New Testament. Edited by G Kittel. Translated by GW Bromiley. Grand Rapids: William B Eerdmans Publishing Company). Unlikely is the claim of Van der Horst (19721973, 184-185), who purports to have found a parallel to "putting off the old person" in a fragment referring to Antigonus of Carystus. The apparent parallel is more about inconsistency of behaviour than an intentional removal of inappropriate behaviour. There is no evidence that this statement or the phrase from Dionysius of Halicarnassus had any influence on the NT.

16 As Chen (2003a, 361-393).

17 Interestingly, the English word "person" derives from the Latin "persona," an actor's mask. A mask is something that actors "put on" in order to be identified as characters in a play. To put on a person is thus to change identity and be conformed to a different life, behaviour and culture. See footnote 15 above.

18 On configuration and reconfiguration as socio-rhetorical features see Robbins (1996a, 40-50).

19 Socio-Rhetorical Interpretation has been developed by Robbins and is discussed by him in many of his writings. For a description of how it has emerged see especially Robbins, VK Forthcoming. Socio-Rhetorical Interpretation. In Blackwell Companion to the New Testament. Edited by DE Aune. Oxford: Blackwell. Many scholars are taking up Robbins' ideas and applying them to various texts. Much fruit from the work of Robbins and others now working with him is forthcoming in a series called "Rhetoric of Religious Antiquity."

20 Robbins (forthcoming). 
ideological and sacred aspects of texts to come to an understanding of how these dimensions of language move people to beliefs, points of view and actions. SocioRhetorical Interpretation recognizes that Early Christians found that they needed new ways to speak and write in order to address their new faith understandings and the new social environment within the Christian community. What developed were multiple modes of Christian discourse that are now being called "rhetorolects." 21 "A rhetorolect is a form of language variety or discourse identifiable on the basis of a distinctive configuration of themes, topics, reasonings, and argumentations." 22 These rhetorolects have within them various "textures" that include sensory-aesthetic, socio-cultural and ideological features and effects which, in turn, have faith, social, ethical and political implications that convey meaning in many ways. ${ }^{23}$ Topics (topoi) within the textures and rhetorolects are elaborated by pictorial narration referred to as "rhetography," and by argumentation called "rhetology." 24 The rhetorolects blend rhetography and rhetology together in order to move audiences toward appropriate understandings and behaviours. ${ }^{25}$ Some aspects of this approach are particularly helpful for examining the garment rhetoric of putting on a person because they help interpret how some Early Christians reshaped the ways in which they thought about themselves and their environment and how they should live and behave in it. One of these ways was through the imagery and rhetorical argument of changed clothing that uses visual, narrative, rhetographic, highly textured modes of discussion to reconstitute the body in a new way and, at the same time, destabilizes and deconstructs an older image of the body seen to be inappropriate in the new community.

\section{Galatians 3:27}

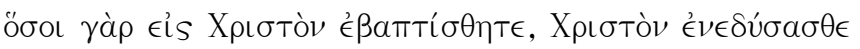

This rhetoric of putting on Christ stands in a context where Paul is, overall, employing the prophetic rhetorolect. ${ }^{26}$ Galatian Gentile Christians have been persuaded to think that it is necessary to observe the Torah (particularly certain parts of it, e.g., circumcision). Paul, here as prophet, aims to communicate what he believes is in fact the will of God by arguing that the law did not bring the Spirit to the Galatian Christians, but that it came out of

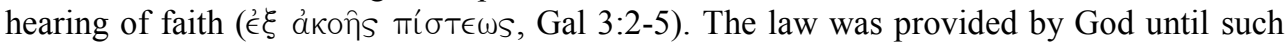
time as the promise to Abraham (Gal 3:6-18) had been fulfilled, until faith had come (Gal

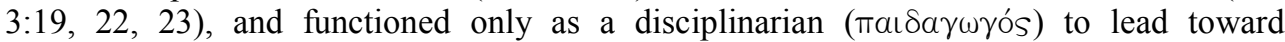
justification by faith (Gal 3:24). The promised faith to come is the faith of Jesus Christ

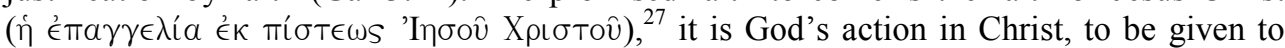

21 Robbins (forthcoming). The rhetorolects are wisdom, prophetic, miracle, precreation, priestly and apocalyptic.

22 Robbins (forthcoming).

23 On "textures" see Robbins, VK 1996b. The Tapestry of Early Christian Discourse: Rhetoric, Society and Ideology. London: Routledge, 44-235; Robbins 1996a, 7-131.

24 See Robbins (forthcoming).

25 See Robbins (forthcoming). By now, Socio-Rhetorical Interpretation is moving on to see how "critical spatiality theory" and "conceptual blending" can be employed to understand the nature of the rhetorolects of early Christian discourse.

26 On argumentation in the prophetic rhetorolect see Robbins, VK 2002. Argumentative Textures in SocioRhetorical Interpretation. Pages 27-65, 44-50 in Rhetorical Argumentation in Biblical Texts. Edited by A Eriksson, TH Olbricht and W Übelacker. Harrisburg: Trinity Press International.

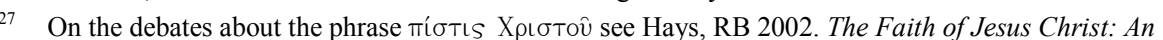
Investigation of the Narrative Substructure of Galatians 3:1-4:11. Grand Rapids: William B Eerdmans Publishing Company; Hays, RB 1997. ПI $\Sigma T \mathrm{TI} \Sigma$ and Pauline Christology: What is at Stake? Pages 35-60 in 
all who believe, who trust (Gal 3:22) as did Abraham (Gal 3:6). All, including the Gentile

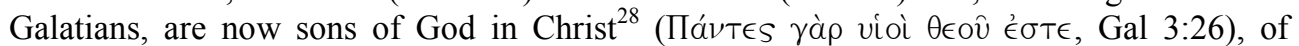

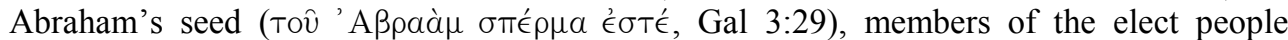
along with Israel. This new identity is marked, according to Paul, by the Galatians' baptism that indicates they have put on, clothed themselves with Christ.

Paul uses the pictorial narration that Socio-Rhetorical Interpretation refers to as rhetography throughout the passage. Audiences are to imagine the "foolish Galatians" (Gal

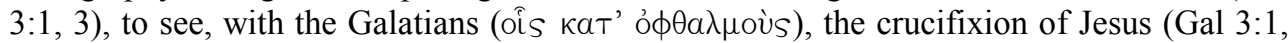
13), miracles (Gal 3:5), Abraham and his descendants (Gal 3:6-9, 16), the writing of wills

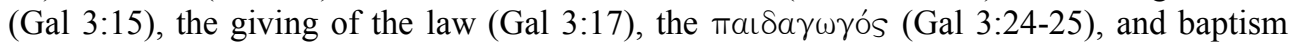
indicating being clothed with Christ (Gal 3:27). Rhetography, then, carries the argument along. In v. 27 the double image to be pictured in the mind is that of baptism and of putting on a person, Christ. ${ }^{29}$ This visual imagery, something that with words mentally engages the eyes and perhaps the sense of touch with the imagined feeling of clothing and fabrics, indicates a sensory-aesthetic texture. ${ }^{30}$ Audiences are to visualize people presented in a specific garment, and, as we have noted, garments make a visual, sensory and aesthetic impact on both wearers and observers. What does this clothing look and feel like? In what way is it attractive? Since the clothing is a person we do not, of course, know what it looks and feels like in a literal physical and physiological sense. The presentation is, nevertheless, made by means of newly clothed bodies. This is how the Galatian Christians are now observed. Their baptism displays them in a new way and they are now recognized by their appearance in the new clothing. From a sensory-aesthetic point of view they are to see themselves and be seen by observers as people recognized by their relationship to Christ rather than to the rules of the Torah. They are to be seen (sensed) not as fools (Gal 3:1), but as Abraham's seed (Gal 3:29).

The rhetography of baptism and clothing indicates the presence of cultural, social and historical intertextures. ${ }^{31}$ Cultural intertexture relates to the knowledge audiences already have because they are members of a culture or know something about other cultures. ${ }^{32}$ The terminology used in a text is known, recognized and hence understood. The audiences of Galatians (that is, the first "Galatian" audience and other informed audiences of the letter since then) will recognize the reference to baptism since it was a feature of their Early Christian culture. Indeed the reference to baptism in Gal 3:27 draws on what members of the Galatian and other Christian cultures know about its significance. It is a part of a known tradition. Similarly, the notion of being clothed is an accessible cultural idea to readers of Gal 3. Clothing and fashion says something about their identity and their presentation to other people. Their new clothing presents them in a distinctly Christian way. Social intertexture relates to common knowledge without regard to cultural location or knowledge. ${ }^{33}$ Audiences

vol. IV of Pauline Theology. Edited by EE Johnson and DM Hay. Atlanta: Scholars Press; and Dunn, JDG 1997. Once More $\Pi I \Sigma T I \Sigma$ XPI $\Sigma$ TOr. Pages 61-81 in vol. IV of Pauline Theology. Edited by EE Johnson and DM Hay. Atlanta: Scholars Press.

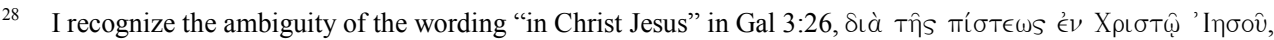
but opt for the interpretation as in NRSV, "for in Christ Jesus you are all children of God..."

29 Cf. Martyn's translation: "For when all of you were baptized into Christ, you put on Christ as though he were your clothing." Martyn, JL 1997. Galatians. Anchor Bible 33A. New York: Doubleday, 373.

30 Robbins (1996a, 29-36)

31 Robbins (1996a, 58-68).

32 Robbins (1996a, 58).

33 Robbins (1996a, 62-63). 
of Galatians are naturally aware of conventions of clothing and so will know something of its meaning. The Galatian Christians will know that Paul, by referring to their new clothing, alludes to the social identity as believers in Christ indicated by clothing, to the way that clothing displays bodies, and to the larger point that they are, in Christ, children of God through faith, not by the observance of the law. Historical intertexture relates to actual events that people know about. ${ }^{34}$ The Gentile Christians of Galatia will be reminded by Paul's statement that they had indeed been baptized at some specific time and place and that their baptism signified clothing themselves with Christ. What Gal 3:27 has done, then, is to bring cultural, social and historical knowledge into view through a rhetoric of clothing. Clothing has been invited into the discourse so that the range of ideas that it can bring about in audience minds can be effective. The rhetoric of clothing is employed to help bring out what is actually determinative for the Galatian Christians, that is, the coming of faith. Faith has come with Christ and the feelings and ideas communicated by the language of being clothed with Christ help drive that point home.

Where does this knowledge and rhetoric of clothing take people? This question leads to the ideological texture ${ }^{35}$ and the political implications of putting on Christ as clothing in Gal $3: 27 .^{36}$ Ideology is to be found in the "rhetorical goal" that texts aim to achieve among their readers. ${ }^{37}$ The task of the examination of ideological texture is to come to an understanding of how texts move people to take a point of view, to come to a particular mindset or worldview, to subscribe to a particular political or economic standpoint or to a particular religious creed, to come to a particular belief and to behaviours related to or based on such things. Ideology is about using power to get people to think and to act in particular ways. In texts ideology is about the rhetorical power of words and language to evoke pictures and arguments that move their audiences to think and act in particular ways. According to Bloomquist, "Texts do not just evidence preexisting worlds; they create them." ${ }^{38}$ Texts bring about change, and the study of how they do this and what they produce is the study of ideological texture. ${ }^{39}$ The rhetoric of clothing has this creative ability in the way that the topos clothing can show not only that a body is covered, but also how it is being displayed in order to make (or create) a point. ${ }^{40}$ Clothing itself displays ideology.

In Gal 3:27, the topoi of baptism and putting on clothing are intertwined to create a response. The desired response is the recognition that faith has come and that believers are

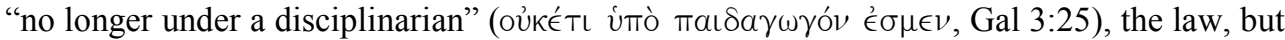
are "children of God through faith" (Gal 3:26) and "Abraham's seed" (Gal 3:29). This desired response is evoked by the image or topos of baptism and how it is elaborated by the

34 Robbins (1996a, 63-68).

35 Robbins (1996a, 95-119). Helpful examples of the study of ideological texture in biblical texts are found in the essays by Combrink, BHW, JS Kloppenborg, DB Gowler, LG Bloomquist, CA Wanamaker, RB Sisson and WH Wachob. 2003. Pages 1-280 in Fabrics of Discourse: Essays in Honor of Vernon K Robbins. Edited by DB Gowler, LG Bloomquist and DF Watson. Harrisburg: Trinity Press International.

36 Betz, HD 1979. A Commentary on Paul's Letter to the Galatians. Hermeneia. Philadelphia: Fortress, 189, footnote 67 , points out that commentators have often denied any political implications to Paul's statements, particularly those of Gal 3:28, claiming they are solely religious.

37 On this see Bloomquist, LG 2003. Paul's Inclusive Language: The Ideological Texture of Romans 1. Pages 172-176 in Fabrics of Discourse: Essays in Honor of Vernon K. Robbins. Edited by DB Gowler, LG Bloomquist and DF Watson. Harrisburg: Trinity Press International.

38 Bloomquist $(2003,176)$

39 As Bloomquist $(2003,173)$, points out: "Thus, a programmatic analysis of ideological texture involves some way to get at choices and movements."

40 See again the effect of clothing as described by Chen (2003a, 361-393) in Maoist China. 
image or topos of putting on Christ. Baptism, here, is the act of putting on Christ as a garment, thereby providing a new presentation or picture of oneself and of all who have

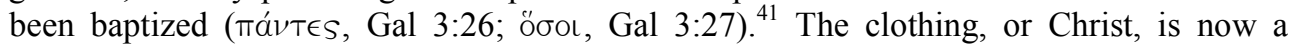
determinative identity marker, itself as clothing creating new identity, a new and different display of the people wearing it that demands different perceptions of them. This clothing ideologically envisions and portrays the new social situation of Gal 3:28 where all are one

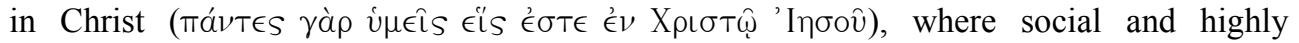
politicized divisions are gone. The perception that Galatian Christians must maintain their status before God by themselves, that is, by observance of the law in their own bodies, ${ }^{42}$ is deconstructed. Old clothing is implicitly deconstructed or removed and the new clothing is worn now in a new ideological situation that has observable results. Galatians 3:27 is not only an encouragement to recall baptism, but is a call for believers to think about the garment they now wear and the rhetorical meaning that the garment presents to themselves and to the world around them. The new clothing is ideologically powerful, indeed it is power, because it influences wearers and observers to want to live in the new situation of faith and social unity. The new life situation is a good situation. This is, clearly, very like the ideological intention and result of the use of clothing in Maoist China, as Chen ${ }^{43}$ has pointed out. Those who are now clothed with Christ are also now Abraham's seed, inheriting the promises to Abraham and so are ideologically identified with Abraham and the promises to Israel. ${ }^{44}$ They, though remaining Gentiles, are in the political stream that descends down to them from Abraham. They are in a continuum from Abraham as sons of God, apart from Israel's law, now without socio-political barriers between them. ${ }^{45}$ Their new clothing conveys this message to them and to others. This counters the ideology of the false teachers in Galatia who tried to shape Gentile believers to an identity (or clothing) of law. It is the new clothing that identifies the nature of the new identity. Paul's statement about putting on Christ is prophetic, ${ }^{46}$ in line with the prophetic rhetorolect being employed. The message from God is that believers now wear Christ as clothing and therefore have an identity and social condition defined by Christ himself and not by their own activities that are performed in accordance with the law.

\section{Romans 13:14}

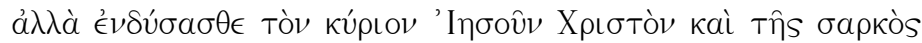

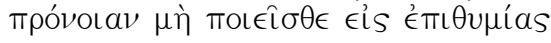

Of the passages being considered here, Rom 13:14 is closest in actual wording to Gal 3:27. ${ }^{47}$ But, unlike Galatians, in Romans the words are set in a distinct paraenetical

41 Many commentators suggest a connection between Gal 3:27 and a supposed baptismal liturgy and with the early practice of baptizands removing their clothing when entering the baptismal water and putting on new robes when leaving it. Such a practice is not dated, however, before the second century.

42 Most graphically, of course, in circumcision.

43 Chen (2003a, 361-393).

44 Cf. Martyn (1997, 374, 377-378).

45 The removal of socio-cultural barriers does not mean that ethnic, gender or social particularities no longer exist, but that they must no longer separate people who wear Christ as clothing. See Buell, DK and CJ Johnson. 2004. The Politics of Interpretation: The Rhetoric of Race and Ethnicity in Paul. Journal of Biblical Literature 123(2):235-251.

46 It is also apocalyptic in that it is describing the new reality brought about by the coming of the Messiah.

47 Perhaps for this reason many scholars claim there is an allusion in Rom 13:14 to baptism. Paul is not here, however, calling for people to be baptized again nor is it necessary to see any reference to baptism at all in 
(wisdom rhetorolect) context as is the language of putting on a new person in Colossians and Ephesians. The verb $\dot{\epsilon} v \delta \dot{w} \omega$ occurs as an imperative. In Romans the words call for people to do what Galatians speaks of having already been done. In addition, the exhortation is set in an eschatological frame where behaviour that makes no provision for the flesh $(\sigma a ́ p \xi)$ that leads toward lust $(\dot{\epsilon} \pi \imath \vartheta v \mu i \alpha)$ is practiced in light of the apparently imminent arrival of salvation and the metaphorical light of day (Rom 13:11-12). There is an eschatological motivation for the action of putting on Christ. All this is the language and thought of the wisdom rhetorolect where the discourse is intended to move people to produce goodness and righteousness through their behaviour. ${ }^{48}$

In socio-rhetorical terms the directive to "put on the Lord Jesus Christ" indicates the

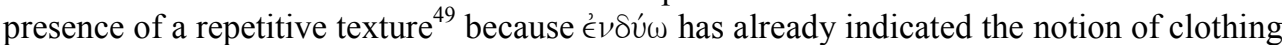

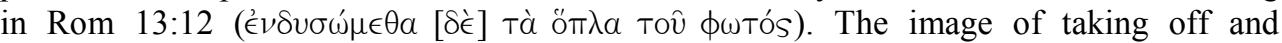
putting on garments will be in audience members' minds before they come to the thought of putting on Christ. There is, then, a clear rhetography of clothing, along with the pictorial narrative about appropriate time, of waking from sleep, of the time when audiences became believers, of night, and the revealing nature of day and of putting off the "works of darkness" (Rom 13:11-13). There are also rhetographs of what are considered to be unacceptable behaviours (Rom 13:13). By contrast ( $\dot{\alpha} \lambda \lambda \dot{\alpha})$ to these activities, readers are to visualize the act of clothing themselves with good things. This rhetography provides a sensory-aesthetic texture as was observed in Gal 3. The images connected with the body and its senses are quite prominent: Waking from sleep, putting off clothing, putting on clothing, the possibly recognizable senses connected with drunkenness, debauchery, licentiousness, quarreling, jealousy, and lust. Audiences are to be aroused by this texture to imagine, indeed to feel, (perhaps by recalling the sensations) these things occurring in their own bodies. Again, by contrast, they can visualize and sense themselves putting on the Lord Jesus Christ as a garment, indicating that they are separated from the old garments and old ways, now making no provision for the flesh. In this garment they appear in a new fashion, clothed in something obviously good and displayed in a way that demonstrates a way of life that stands against the things of darkness and the flesh. As did the rhetography of Gal 3, the imagery in Rom 13:14 includes cultural and social intertextures. The use of clothing and the significance of undressing and redressing are well-known cultural images that suggest alterations to the activities in which people engage and how they are viewed and understood when engaging in the activities. Audiences of the text will also be conscious of the social conception of how clothing and altered clothing makes statements about the wearer's identity. Also at work here is an apocalyptic or eschatological intertexture in the reminders of the time and the nearness of salvation. It seems obvious that Christians in Rome, on hearing these words, would immediately be aware of their previously learned knowledge of an imminent parousia. This intertexture is part of the rhetographic argument that supports the importance of putting on Christ as a garment.

Ideologically, putting on the Lord Jesus Christ calls for a new display of believers collectively ${ }^{50}$ in a particularly behavioural way. The explicit order to remove the old clothing of the works of darkness destabilizes and deconstructs the negative power of

this verse. The point is, rather, about how believers present themselves to the world, in light of eschatological expectation. Cf. Dunn (1988, 790-791).

48 See Robbins (forthcoming).

49 Robbins (1996a, 7-8).

50 The verb forms and pronouns are plurals thus envisioning a collective rather than individual redressing. 
darkness. Indeed when the new clothing is worn there is to be no provision made at all for things of the flesh. ${ }^{51}$ Questionable behaviour is gone and the garment of Christ is strongly suggestive of the practice of behaviour that is beyond any question. The rhetoric of bodies clothed with Christ is a strong communicative device that elicits a "reconstitution of the mind,, 52 creating a world that displays what believers can imagine Christ himself displaying, bringing about, in turn, reconfigured views of how people can and should live. ${ }^{53}$ Displaying Christ in this way promotes conformity to the ideology that behaviour in view of the parousia is an important consideration. This ideological rhetoric of clothing bodies, too, flows out of the hortatory rhetoric that began in Rom 12:1-2, where believers are called to present their bodies as living sacrifices, where their minds are to be transformed in order to discern the will of God. ${ }^{54}$ This is an ideology and political presentation of what Paul perceives to be Christian identity. ${ }^{55}$ The clothing has the power to encourage humans who are conscious of the various desires of the flesh to "walk respectably" ( $\epsilon \dot{v} \sigma \times \eta \mu o ́ v \omega S$ $\pi \in \rho \iota \pi \alpha \tau \dot{\sigma} \sigma \omega \mu \in \nu$, Rom 13:13) in their lives.

\section{Colossians 3:8-10}

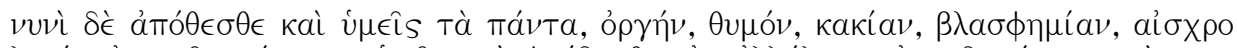

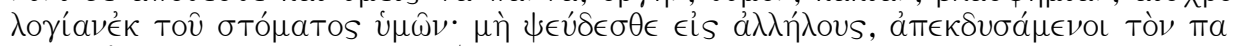

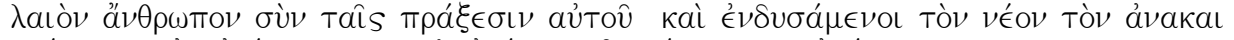

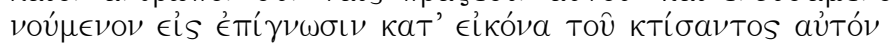

The most obvious difference of language in Col 3:8-10 (and Eph 4:22-24) is that the person who is put on as clothing is not explicitly Christ as it is in Gal 3:27 and Rom 13:14. Here the explicit term is $\ddot{\alpha} \nu \theta \rho \omega \pi$, "person." ${ }^{56}$ A second difference is that "stripping off"

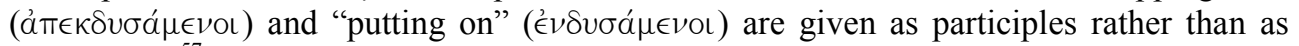
imperatives. ${ }^{57} \mathrm{~A}$ third is that Colossians uses the word $\dot{a} \pi \epsilon \kappa \delta \dot{\omega} \omega$ rather than $\dot{\pi} \pi \circ \operatorname{ti}^{\prime} \theta \eta \mu$ to describe stripping off the old person. The context is clearly paraenetical, and a wisdom rhetorolect, where behaviour that accords with life that is now hidden with Christ in God (Col 3:2) is encouraged. There are clear injunctions in Col 3:5-9 for believers to rid themselves of known vices. The "having stripped off" and "having put on" sequence, however, understood not imperativally but as a description of something already accomplished, is not a directive to take on good behaviours, but is a basis for the directives

51 Which flesh audiences of Romans who have read the entire letter in sequence will recall. See Rom 6:23; 7:5$25 ; 8: 1-17$.

52 Chen (2003a, 361).

53 That this ideological rhetoric can have such powerful effect is illustrated by how Rom 13:13-14 is reputed to have brought about the conversion of Augustine to Christian faith. See Dunn $(1988,793)$.

54 On the rhetoric of Rom 12 see Jeal, RR Forthcoming. Melody, Imagery and Memory in the Moral Persuasion of Paul. In Rhetoric, Ethic and Moral Persuasion in Biblical Discourse: Essays from the 2002 Heidelberg Conference. Edited by TH Olbricht and A Eriksson. New York: T\&T Clark International.

55 Fitzmyer, JA 1993. Romans. Anchor Bible 33. New York: Doubleday, 682, claims too much by stating that "the baptized become another Christ." Believers do not become the Lord Jesus Christ themselves, rather they wear Christ as clothing and are identified by the clothing.

56 The nuanced renderings such as "self" or even "old nature" and "new nature" in some translations, or that $\ddot{\alpha} \nu \theta \rho \omega \pi$ os refers to the good deeds themselves, are misleading.

57 Whether these participles are to be taken in an imperatival or adverbial sense is debated, but the adverbial sense is likely because the participles then stand as the basis for the exhortations and agree with the transformation discussed earlier in Col 2:6-15 and 3:1-4. See O'Brien, PT 1982. Colossians. Word Biblical Commentary 44. Dallas: Word, 218-219; MacDonald, MY 2000. Colossians and Ephesians. SacraPagina 17. Collegeville: Michael Glazier, 137. 
and, rhetorically, makes the argumentative move toward the good behaviours indicated in Col 3:11-15. Since believers have put on the new person and since that new person is undergoing continuing renewal, they should display behaviour that is in harmony with the clothing now worn. Many interpreters associate "having stripped off the old person" and "having put on the new person" with the imagery of baptism as seen already in Col 2:11-14 and Gal 3:27. ${ }^{58}$ Baptism may form an interesting intertexture here, but there is no explicit or causal reason to assume that it is the referent or necessarily in mind. ${ }^{59}$ What is in mind has more to do with what baptism can, in part, stand for, a separation from sin, than echoes of baptism itself. The rhetography is, nevertheless, quite apparent with the pictures of putting to death, of various evil activities, and of undressing and redressing noted in Col 3:4-10.

As in Rom 13, there is a repetitive texture at work on audience thinking because the

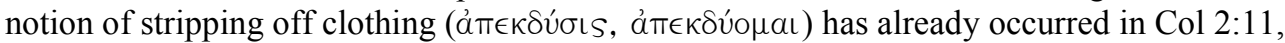
15. The notion of putting on clothing ( $(\mathcal{\prime} \nu \delta \dot{\omega} \omega)$ recurs in Col 3:10 and 3:12, and is implied in $\mathrm{Col} 3: 14$. The result is that undressing and redressing are thoughts clearly in mind, used as topoi that help carry meaning along. Again as in Rom 13, there is a strong sensory-aesthetic texture palpable not only through the senses of the sight and feeling of bodies clothed with either an old or a new person, but also in the bodily senses aroused by the thought of actions like the anger, rage, evil, blasphemy, obscene speech and lying mentioned in Col $3: 8-9$. Most of these sensory features are focused on the use of the mouth and are actions that are self-disclosing about people and the lenses through which they see the world and other people. ${ }^{60}$ The sensory texture of stripping off and putting on clothing extends into historical intertexture as readers recall that they have, at some previous time, undressed and redressed by becoming believers in Christ. Cultural and social intertexture plays the same role that they do in Gal 3 and Rom 15.

It is ideological texture that stands out prominently in the imagery of putting on the new person. ${ }^{61}$ The new person who has been put on is not, strictly speaking, what believers have become. Believers are not described as the new person who is now to be understood as some new humanity or new personality. ${ }^{62}$ More correctly, the new person is the clothing that believers have put on. The new person is what one wears. The old person was not the

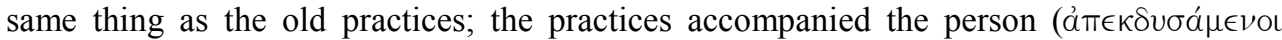

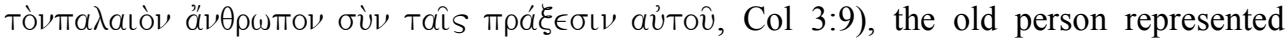
those practices, and the garment worn displayed people as those who engaged in the practices. Similarly, the new person is not the good practices of Col 3:11-15. Rather, the new person/garment displays the good practices. Thus, just as wearing the old person represented a way of behaving in life, so wearing the new person represents $a$ way of behaving and living in life. In other words, what is important is not merely what the clothing is, what is important is what the clothing does, what it brings about and how it brings about ideas and action. The new garment identifies one's new belief, thereby

58 As for example, Lohse, E 1971. A Commentary on the Epistles of Colossians and Philemon. Hermeneia. Philadelphia: Fortress, 141-142; MacDonald (2000, 136, 145-147).

59 Cf. Barth, M and H Blanke. 1994. Colossians. Anchor Bible 34B. New York: Doubleday, 409; Lincoln, AT 2000. Colossians. The New Interpreter's Bible XI. Nashville: Abingdon, 643.

60 See Robbins (1996a, 30-31).

${ }^{61}$ For the views of interpreters who perceive connections between the old and new persons and Adam-Christ typology, mysticism, corporate notions of new humanity and other ideas, see the commentaries.

62 As for example, O'Brien (1982, 190-191); Lincoln (2000, 643); Dunn, JDG 1996. The Epistles to the Colossians and to Philemon. New International Greek New Testament Commentary. Grand Rapids: William B Eerdmans Publishing Company, 227. 
identifying who a believer now is, and the new garment also displays, sets forward, conveys to the believer and to all observers a new appearance in the world. The presence and observability of the new clothing already in the present urges the behaviour that it implies on both wearer of the garment and on those who see it. The clothing itself brings about an altered religious, social and behavioral situation among the redressed people. This is an ideological effect with significant persuasive and political implications. The clothing itself is powerful, creating a new condition for the bodies that wear it and promoting conformity to it. The metaphorical physical transformation elicits a reconstitution of the mind and, with it, behaviour. What is brought about by means of the reconstituted mind is very like what was noted in Gal 3:28-29: A new situation of faith and unity where ethnic, religious and social barriers have been deconstructed (3:11), where all are treated carefully and respectfully (3:12-13), where love, which is also put on as a garment, is the bond of perfection (3:14), and where the peace of Christ rules (3:15). Ethnic, religious, and social distinctions are no longer important markers in human life. The "visible," "sensory," marker is not the replacement of vices with virtues, but the replacement of old clothing with new that displays a new reality. The clothes make the (wo)man.

\section{Ephesians 4:22-24}

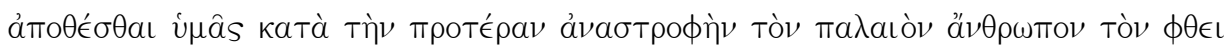

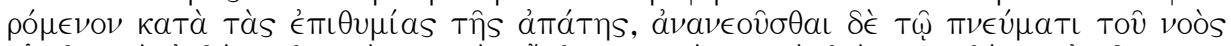

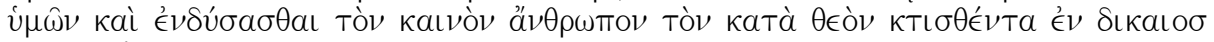

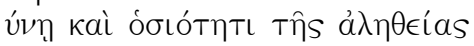

In the paraenetical context (Eph 4:17-25, overall a wisdom rhetorolect) in which these verses are set, believers are exhorted to abstain from inappropriate behaviour (the way

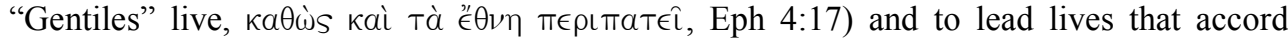

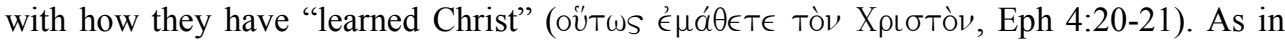
$\mathrm{Col} 3$, there are clear injunctions to stop engaging in some specified activities and to practice others that are reminiscent of vice and virtue catalogues. ${ }^{63}$ Here the "stripping off"

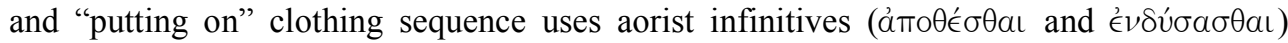
rather than imperatives (as Rom 13:14) or participles (as Col 3:8-10). While there has been debate about whether these infinitives (with a third, present passive infinitive,

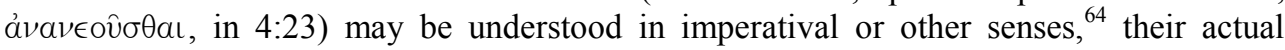
function is to remind audiences of the undressing and redressing that has already occurred. The infinitives, then, reflect imperatives that were likely given and followed at some earlier time, followed also in the past by the change of clothing. As in Col 3:8-10, then, the clothing rhetoric does not itself function as a call for a change of behaviour, but is used argumentatively, as rhetology, urging audiences to recall a change already made in order to support the present exhortation. Again, as with Col 3:8-10, many interpreters state that the undressing and redressing imagery is a direct reference to baptism, to a baptismal liturgy, and to the disrobing and rerobing thought to have been already practiced by the time of writing of Ephesians. ${ }^{65}$ But none of these things associated with baptism are explicit here and it is not necessary to think that they are in mind or that they in themselves explain the

63 The intertexture with Colossians is fascinating, but beyond the range of things to be done in this essay.

64 See discussion in the commentaries, e.g., Hoehner, H 2002. Ephesians: An Exegetical Commentary. Grand Rapids: Baker, 599-602; Lincoln, AT 1990. Ephesians. Word Biblical Commentary 42. Dallas: Word, 283284.

65 For example, MacDonald (2000, 304-305). 
rhetoric. ${ }^{66}$ It is the explicit rhetography of undressing and redressing with garments that are old and new persons ${ }^{67}$ that is central to the exhortations.

The rhetography of the verses casts images of people that readers would recognize, indeed in which they would recognize themselves in a former existence as Gentiles (who have now been brought near to Israel and salvation; cf. Eph 2:11-16). The description is of the Gentile mind of darkened understanding, of alienation from God due to ignorance, of insensitivity, and of abandonment to evil practices (4:17-19). This "Gentile" picture presents a strong cultural intertexture that reminds of how an entire group had been characterized. The contrasting cultural intertexture is that of the believing community that has "learned Christ" and practices that all would agree are good behaviours. These pictures are graphic in the way they inform readers of some of the realties of life in the world and, particularly, in how they remind them of what has happened and should happen in their own lives as believers. This rhetography on its own prompts audiences to remember and agree with what is being described.

This texturing is elaborated by the garment topoi of stripping off the corrupt old person and of putting on the new person, bringing into view how the cultural and social identities are worn and thus cover visualized bodies so as to classify and display them. The old garment, the old person, is intended to evoke sensory-aesthetic notions of something that was very unattractive, that was an identifier and classifier of the "Gentile" mindset and behaviour that displays futility, darkness and alienation (4:17-18). The old garment marks off those who have not learned Christ. The rhetoric of a "new person" has already been

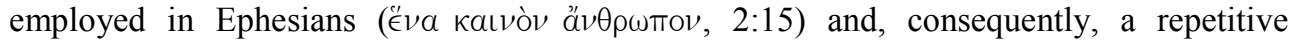
texture in the larger unit of Ephesians is formed when the words are repeated in Eph 4:22. Audiences will already have a feel for the idea and its meaning when it appears in Eph 4:22. The "one new person" of Eph 2:15 is comprised of Gentiles and Jews and has been made so by Christ (Eph 2:13-15) so that both groups might be reconciled to God (Eph 2:16). This is instructive for how the new garment as a person is to be understood: The repetitive texture suggests to audiences that the new person is one whom Christ has made out of separate, disparate things or persons. By contrast, the old person may be expected to be divided, separated, experiencing disunity in the world and "alienated from the life of

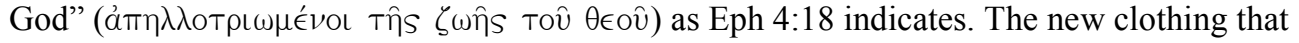
is a person is the now saved and reconciled humanity. This new clothing is attractive and is meant to appear as something that readers of Ephesians would want to keep on wearing and by which they would be happy to be identified and described. The fabric of the garment is woven by Christ out of formerly separated and hostile materials that now, in its unity, displays a new reality.

Ideological texture is of special interest here. Believers are not displaying what they are on their own in their bodies or by their own merits, but, in their new clothing they are displaying what Christ has made in order to bring about change in the world. As in Col 3, the old person is not the evil practices and behaviours themselves, nor is the new person the good practices and behaviour themselves. It is, rather, the new person worn on the bodies of believers, portraying what Christ has done for humans by destroying the things that separated human groups from each other (Eph 2:11-15). The new clothing has been

66 Cf. Barth, M 1974. Ephesians 4-6. Anchor Bible 34A. New York: Doubleday, 506-507.

67 As observed for Colossians in footnote 56 above, nuanced translations of $\alpha$ $\alpha \theta \rho \omega \pi$ os do a disservice to meaning. On this in Eph 4:22-24 see Delasanta, R. 2002. Putting off the Old Man and Putting on the New: Ephesians 4:22-24 in Chaucer, Shakespeare, Swift and Dostoevsky. Christianity and Literature 51(3):339362. 
manufactured by Christ and it moves people toward an ideological sensibility relative to other bodies wearing the same clothes: Behave well relative to them. At the same time it indicates a boundary by being a fashion that distinguishes the wearers from others in the world ("Gentiles") who behave badly. The clothing itself is thus creative, doing something for both wearers and observers. ${ }^{68}$ It is important to distinguish, again, between the clothing and the persons who are being encouraged to behave in specific ways. They are not the same. Interpreters frequently blur the lines between the new person who is a garment and believers who as (new) persons in Christ practice appropriate behaviours. The wearing of the new person encourages the new way of life in contrast to the former "Gentile" way. It is clothing that here brings about an ideological shift that persuades the Christians to behave in social and religious ways appropriate to the garment worn. Clothes make the (wo)man and the wearing of them is a political act that provides the wearer with a refashioned ideological identity and tends to bring about in wearers' and observers' bodies the same refashioning of identity, ideology and behaviour. Believers portray through their new clothing "the demeanour of the community - its public persona," 69 the public face that has the power to influence how people think and behave.

\section{Conclusion}

The title of this essay is obviously picking up on the old expression "clothes make the man" and attempts to make it inclusive by altering it to "clothes make the (wo)man." The term is, however, not merely a trite saying when seen in the light of the NT rhetoric of being clothed with a person. What this essay is claiming is that the NT passages considered here demonstrate an awareness of the ability of the imagery of garments to elicit transformation in human lives. The new clothing of a person, of Christ (Gal 3:27 and Rom 13:14) or of the new $\stackrel{\alpha}{\nu} \theta \rho \omega \pi$ Tos (Col 3:8-10 and Eph 4:22-24) is meant to display Christians in a distinctly Christian way, bringing into view a particular knowledge not otherwise easily seen. The new clothing influences people to think and live in a situation of faith and social unity. The new clothing evokes a "reconstitution of the mind" that brings about reconfigured behaviour in accord with the nature of the clothing worn and displayed. The important ideological power of the clothing imagery is found not simply in what the clothing is, but in what it does, in what it creates. The new clothing creates a new condition for the bodies that wear it and promotes conformity to the nature of the clothing. The new clothing is meant to promote conformity to Christ and to the new reconciled being that Christ has made. Just as in Maoist China, the imagery of physical transformation brings about an intellectual transformation where "old" cultural, and social barriers are deconstructed and no longer employed. A change of clothing draws attention to a new politic where there is peace, community and genuine care for people, thus developing a new aesthetic. ${ }^{70}$ The redressed body indicates a reshaped human person. It is true that "clothes make the man or woman" in the sense that they bring about ideological and political change.

Putting on a person, so clothing the body, is fundamentally a political act. It is not only a religious act of the individual because clothing shows that a claim has been made on the body and, therefore, on the public appearance and activity of people so clothed and on observers of them. "Things are not the same any more" for bodies that are wearing a person. The change of garment brings about changes of perception, of understanding, even

68 Cf. Barth $(1974,540-541)$.

69 MacDonald (2000, 322).

70 Cf. Chen (2003a, 383). 
of notions of intent and goals. This is more than matters of the heart or religious sentiment. It is not only about encouraging people to be well-behaved. It is about a way of viewing the world. In Maoist China, changes of clothing brought about a change of consciousness and a new political identity and ethos among some groups. In the NT passages considered here the same effect occurs. Clothing aids in transforming the citizens of a society. A way of speaking, of using an ancient figure of speech, has been in the NT distinctively shaped and strengthened into something that has a significant effect on how people think and act. Being clothed with a person has become a feature in the making of persons. 